NBER WORKING PAPER SERIES

\title{
RELATIVE WAGES, EFFICIENCY WAGES, AND KEYNESIAN UNEMPLOYMENT
}

Lawrence H. Sumners

Working Paper No, 2590

\author{
NATIONAL BUREAU OF ECONOMIC RESEARCH \\ 1050 Massachusetts Avenue \\ Cambridge, MA 02138 \\ May 1988
}

The ideas in this paper are developed much more fully in summers (1988a) where $a$ much fuller list of references to prior work is provided. I am indebted to Larry Katz for helpful comments on an earlier draft of this paper. The research reported here is part of the NBER's research program in Economic Fluctuations. Any opinions expressed are those of the authors and not those of the National Bureau of Economic Research. 
NBER Working Paper \#2590

May 1988

Relative Wages, Efficiency Wages, and Keynesian Unemployment

\section{ABSTRACT}

While modern economic theorists have produced a variety of explanations for the failure of wages to fall in the face of unemployment, keynes emphasig on relative wages has not been reflected in most contemporary discussions. This short paper suggests that relative wage theories in which workers' productivity depends primarily on their relative wage provide the best available apparatus for understanding actual unemployment and its fluctuations, Such theories are very closely related to the efficiency wage theories that have received widespread attention in recent years.

Lawrence H. Summers Department of Economics Harvard University Cambridge, MA 02138 
Keynes's Genergl Theory in explaining Involuntary unemployment advanced the Idea that "any individual or group of Individuals, who consent to a reduction of money wages relatively to others will suffer a relative reduction in real wages, which is sufficient justffication for them to resist it. On the other hand, it would be impracticable to resist every reduction of real wages due to changes in the purchasing power of money, which affects all workers al1ke." (p.14) While modern economic theorists have produced a variety of explanations for the failure of wages to fall in the face of unemployment, Keynes emphasis on relative wages has not been reflected in most contemporary discussions. This short paper suggests that relative wage theorles in which workers' productivity depends primarily on their relative wage provide the best available apparatus for understanding actual unemployment and 1ts fluctuations. Such theories are very closely related to the efficiency wage theorles that have recelved widespread attention in recent years.

Section I motivates and then lays out a simple relative wage model describing the detemination of equllbrium unemploynent and highlights the fragility of the equilibria that are likely to result when firms are concerned about their relative wage. Section II develops the close relationship between relative wage models and models that stress the role of insider power in understanding unemployment. Section III shows how efficiency wage models can be extended to account for cyclical unemployment fluctuations once the role of relative wages in influencing worker productivity is recognized. Section IV offers some concluding observations. 


\section{Relative Wages and Equilibrium Unemployment}

For simplicity, consider a labor market in which workers and jobs are homogeneous. In addition to the virtue of tractability, these assumptions remove many of the amblguities assoclated with the concept of involuntary unemployment. If the labor market were perfectly competitive and free of information problems, the demand and supply of labor would be equated. In the competitive equllibrium, all firms would pay the prevalifng wege, and any worker would be able to 1mmediately obtaln work at this wage.

This very simple perfect competition model offers a manifestly

inadequate account of the labor markets. Flrms do not act as if they face perfectly elastic labor-supply schedules. Small changes in wages da not produce Infinite changes in the available supply of labor. In fact, firms focus on variables other than the quantity of labor available to them in setting wages. A large institutional literature has documented that firms go to considerable expense to gain information in order to set an appropriate wage rate relazive to other firms in their labor market. In Ghicago aione, more thar. 100 surveys of the wages paid to clerical workers were performed in a sirgle year, while firms went to relatively little expense to determine how many clertcal workers were unemployed. Most strikingly, even in settings where unemployment is high, Eirms do not cut wages and sometimes even salse them.

The natural way for an econonist to account for the observation that Eirms sometimes raise wages even when they are not having trouble staffing their workplace is to postulate that reducing wages in the face of unemployment would reduce profits. Profits may fall when wages are reduced, if reducing wages Influences productivity by affecting workers' effort, or by raising the Firm's 
costs of tecruiting, training and retaining its labor force. This is the central theme of the burgeoning efficiency literature (surveyed by stiglitz (1986) and Katz (1986)) which spells out a variety of mechanisms linking the wages a firm pays to the productivity of lts workforce. While the poinc is rarely emphasized, most efficiency wage arguments suggest that rather than depending on absolute wages, productivity depends on the relative attractiveness of opportunities lnside and outside the firm. Opportunites outside the firm in turn depend on both the wages paid by other firms and the rate of unemployment. Think about storles based on turnover, recruiting, workers' perceptions of what is fair as examples.

A simple functional form allowing for the possibility that increasing relative wages ralses productivity holds that: ${ }^{1}$

(1) $\theta-(\omega-x)^{\alpha} \quad 0 \leq a \leq 1$

where $\theta$ measures the effort put forth by the representative worker, $x$ reflects 1ts workers' opportunities in a sense defined precisely below and $\alpha$ measures the productivity-enhancing effects of paying higher wages. If $\alpha=0$, efficiency wage considerations are absent, Ag a increases, they become more important.

The representative firm's problem is to choose a level of wages that minimizes costs per unit of effective labor 1nput, $w / \theta$. Differentiating (1) ylelds the result:

(2) $w^{*}-x /(1-\alpha)$

which Implies that the firm pays workers their opportunity cost if efficiency wage considerations are absent but generally pays a premlum whose magnitude depends on the the gize of $a$.

Characterizing market equitibrium requires a description of how $x$ is 
determined. A convenient functional form capturing the idea that outside opportunities depend both on wages paid by other firms and on unemployment is:

(3) $x=w(1-(1-b) u)$

where $u$ is the unemploynent rate, $w$ is the average wage pald by other firms, and b reflects thelr relative Importance in determining a workers' outsicle opportunicles. The value of $b$ in a fully worked out model would depend positively on the utility of leisure, the value of unemployment benefits, and negatively on the duration of unemployment.

Substituting (3) into (2) and requiring that w-w, since a1l firms are identical, we obtaln a very simple expression for the market equilibrium unemployment rate:

(4) $u=\alpha /(1-b)$

Equation (4) Indicates that the equilibrium unemploynent rate depends positively on the size of the productivity-enhancing effects of wage increases as reflected in $\alpha$, and on the attractiveness of unemployment as reflected in $b$. Notice that only in the special and plausible case where a=0 will there be no unemployment in equilibrium. Notice that the functional form used here has the special and attractive property that the equilibrium level of unemployment does not depend at all on the form of the labor-demand schedule. The labor-demand curve only determines the level of wages. This is an attractive property of the model. It is striking that real wages have doubled several tiges over the last century without having a large impact on average unemployment rates.

Substituting plausible parameter values into equation (4), it is clear that only small efficlency wage effects are needed to account for observed levels of unemployment. Even if $\mathrm{b}=0$, a productivity-relative wage elasticity, 
$\alpha$, of only .06 is sufficlent to rationalize a 6 percent unemploynent rate. For larger values of $b$, even smaller efflciency wage effects are sufficient to rationalize observed levels of unemployment. Furthermote, the image of unemployment suggested by the model also accords with observation in two important respects.

First, the unemployment generated here is involuntary and gocially costly. In complex models it is sometimes difficult to make the concept of involuntary unemployment operational. But here its meaning is clear enough. All jobs and workers are 1dentical. A1l workers want jobs at the prevailing wages but only some workers can get them. Furthermore, since workers and firms are Identical, the unemployment modelled here does not arise from desirable reallocations of labor power to fts highest value uge. In this sense, it is consistent with observations highlighting the concentration of unemployment among a small segment of the population that experfences long unemployment durations.

Second, the model is suggestive regarding differences between demographic groups In unemployment rates. Those who value leisure highly and whose turnover is quick are most sensitive to relative wages and will have the highest. unemployment rates. Think of teenagers as an obvious example. Alternatively, think of construction workers who can eastly move from job to job.

The determination of equilibrium unemployment in a general relative wage model is depicted in Figure $1 .^{2}$ The equilibrium unemployment rato has the special property that the representative firm optimizes by paying the prevailing wage. At lower unemployment rates, the representatlve firm wants to pay a wage that exceeds that pald by other firms. At higher unemployment rates, it desires 
to pay a wage that is lower than the wage pald by other firms. Notice that as long as the representative firm would like to pay a higher than average wage in the face of completely full employment, the market equilibrium unemployment rate will be positive.

Looking at Figure 1 , it is clear that if the two schedules intersect at a narrow angle, small movements in either schedule will have a large effect on equilibrium unemployment. For instance in the example cited above, a relatively modest increase in the value of the "unemployment benefit," $b$ from .5 to 6 would be sufficient to increase the unemployment rate from 5 to 7.5 percent as the Wh schedule shifted upwards. The sensitivity of the unemployment to small shocks is a consequence of the relative wage nodel's basic logic. Developments that cause some firms to raise wages have their effects magnified because each firm's optimal wage is a postive function of average wages.

The principle, that concerns with conformity can lead to volatility and instability, is a very general one. It must help to explain why the demand for hula-hoops or Rubik's cube is so much more volatile than the demand for more standard products whose value depends less on whether they are used by others. In the next two sections, I argue that conformity effects can help to explain why structural and cyclical unemployment vary so widely.

\section{Relative Wages. Ingider Power and Structural Unemployment}

The preceding discussion has maintained the assumption that firms are able to set wages in order to maximize their profits. A major theme of recent discussions of unemployment particularly in the European context is the idea 
that wageg are set by bargaining, implicit or explicit, between flrms and workers. Such bargaining obviously occurs in union contexts. Lindbeck and Snower's (1987) insider-outsider theorles suggegt that bargaining may be relevant in non-union settings as well. Lindbeck and snower treat insideroutsider theories as an alternative to efficlency wage theories in explaining unemployment.

From the perspective of the model presented in the first section, it seetns more natural to regard them as complementary, mutually relnforcing explanations for unemployment. The relative and efficlency wage considerations stresed in the previous section magnify greatly any effects of bargaining power in two respects. First, in the model developed above, firms reach an interior optimum in setting wages. It is a property of such an optimum that sufficiently small changes in wages have no effect on profits, and larger changes in wages have only second-order effects on profits. This means that in an efficiency rage environment, firms that are forced to pay their workers premium wages suffer only second order losses. In almogt any plausible bargalning framework, this makes it easter for workers to extract concessions. ${ }^{3}$

Second, a key aspect of any relative wage theory is that the optimal wage for a firm to pay depends positively on the wages pald by other firms. This means that when inslders raise wages at some firms, the effect spills over leading other f1rms to rafse their wages. Katz and Dlekens' (1987) survey of the literature reports some evidence that, contrary to the predictions of at least simple competitive theories, the presence of unions in an industry ralses the wages of both union and non-union workers. Similarly, it is often argued that increases in the minimum wage lead to changes in other wages as well in 
order to preserve relativities. Relative wage effects an productivity can explain why insider power can create unemployment, even if there are same freely competitive sectors of the econony.

These two points can be illustrated by a simple calculation. Imagine that insiders at a fraction $\beta$ of all firms have the power to extract a premium of $\mu$ over wages at unorganzied firms. Then the equilibrium unemployment rate may be calculated by solving the equations:

(5) $w^{\circ}-(1+\mu) w^{n}$

(6) $w^{0}-\left(\beta w^{n}+(1-\beta) w^{0}\right)(1-(1-b) w) /(1-\alpha)$

where $w^{\circ}$ and $w^{n}$ represent respectively the wages in the organized and nonorganlzed sectots. This yields:

(7) $u=(\alpha+\mu \beta) /(1-b)(1+\mu \beta)$

Equilibrium unemployment increases with the size of the organized sector and with the size of the wage premlums it can extract. The results of inserting plausible parameter values are striking. Assume, as before, that of .06 and $b=.0$. Then, if $\mu$ and $\beta$ are each equal to .15 , insider power will increase the unemployment rate from 6 percent to 8.1 percent. Yet, union firms incur labor costa that are only 6 percent greater than in non-unionized firms because of the productivity-enhancing effects of wage premia.

The role of relative wages explains why unemployment outcomes are so sensitive to small amounts of Insider power. This comports with the common observation that "corporatist" cauntrles, where labor bargaining is centralized, tend to have lower average rates of unemployment than other nations where bargaining is decentralized. 


\section{Cyclical Unemploymert}

The basic problem in understanding cyclfcal fluctuations involves isolating the Impulses and propagation mechanisms that cause the economy to fluctuate. The relative wage approach to understanding unemployment developed here suggests propagation effects are likely to be strong, and so only small impulses are necessary to account for observed cyclical fluctuations. In particular, the equilibria described in Figure 1 are "fraglie,"-- that is, very sensitive to small disturbances. Small real shocks may have large effects particularly if they are transitory and so do not affect workers' perception of " $x$ " representing outside opportunities.

The relative wage model here suggests that unemployment will be very sensitive to perception errors that might plausibly follow changes in monotary policies. Essentially misperceptions by workers of average wages shift the $E E$ curve in figure 1 upwards. If relative wage effects are strong, even sma11 misperceptions can have large effects. Imaglne that the money stock is reduced, but firms belleve chat the workers who still have jobs do not yet recognize that equilibrum wages have declined. Then it would not be profitable for them to reduce wages to the level that would be an equilibrium if workers did not misperceive their opportunities. Furthermore, flrms that recognized that other firms were not reducing their wages to the new equllbrium level would recognize that they should not either, even if their workers were fully informed.

This misperceptions story is reinforced by two further considerations whtch distinguish it sharply from misperception interpretations of business cycles put forward by classical theorists. First, the central problem here is one of 
coordination. Notice that it is sufficient to prevent reattainment of equilibrium following a shock, for some firms to suspect that some firms will suspect that some firms will suspect that...elther workers or some firms... wiII not assume that the new equilibrium is to be atcalned immedfately. The informational requirement for the costless attalnment of a new equilibrium is much more than individual rationality--it is comon knowledge that all individuals will be rational.

Second, the plausibility of rapid adjustment is further undercut by the observation that, at least in the face of an adverse shock, workers who are perceived as ignorant of the new equilibrium will benefit, in that their wages will not be zeduced. This makes it even less likely that transitions between equilibria will occur smathly. The idea of persistent misperceptions is supported by evidence. Caskey (1985) demonstrates that inflation was consistently underestimated for ten years during the 1970 s and has been consistently overestlmated durting the $1970 \mathrm{~s}$.

The description of wage setting sketched here seems more compeling than the assumption of sticky nominal wages that is contained in "Keynesian" macroeconomics textbooks. Keynesian formulations have been successful in identifying reasons why firms might find it costly or undesirable to vary wages continuously. But most of the reasons they have given for wage rigidity are at least equally plausfble as justifications for keeping the level of employment constant and not firing wozkers during recessions. On the other hand, the misperceptons ldea stressed here explatos why firms choose to adjust wages slowly and fire workers when adverse shockg come. There is also the further point stressed in some of the implicit contracts literature that layoffs help to 
educate workers who have jobs about adverse changes in market conditions.

An analogy developed in Summers (1988b) may be helpful in seeing the point of this gection. Daylight savings time is purely a change in the "units" used in measuring time. Yet it clearly has real effects in the sense that stores open at a different time relative to the sunrise because of its existence. Why? Probably because most individuals care much more about being on the same time standard as their neighbors than they care about what that cime standard is. Therefore, coordinating actions can succed in achieving a better outcome in the sumertine than the market would generate. Much the same may be true of expansionary policy during recessions.

\section{Conclustons}

Unemployment, like cancer, is a multi-faceted phenomenon that comes in many forms. But one would hope that theory could isolate aspects comon to different types of unemployment in different places and times. I suspect that zecognizing the role of relative wages in influencing workers' performance will help economists in understanding different types of unemployment. Keynes emphasized the volatility assoclated with situations where people try to guess the guesses of others in flnanclal marketg. This essay has tried to argue that the lesson is a general one applying to labor markets as well. 
Figure 1

Relative Wages and Equilibrium Unemployment

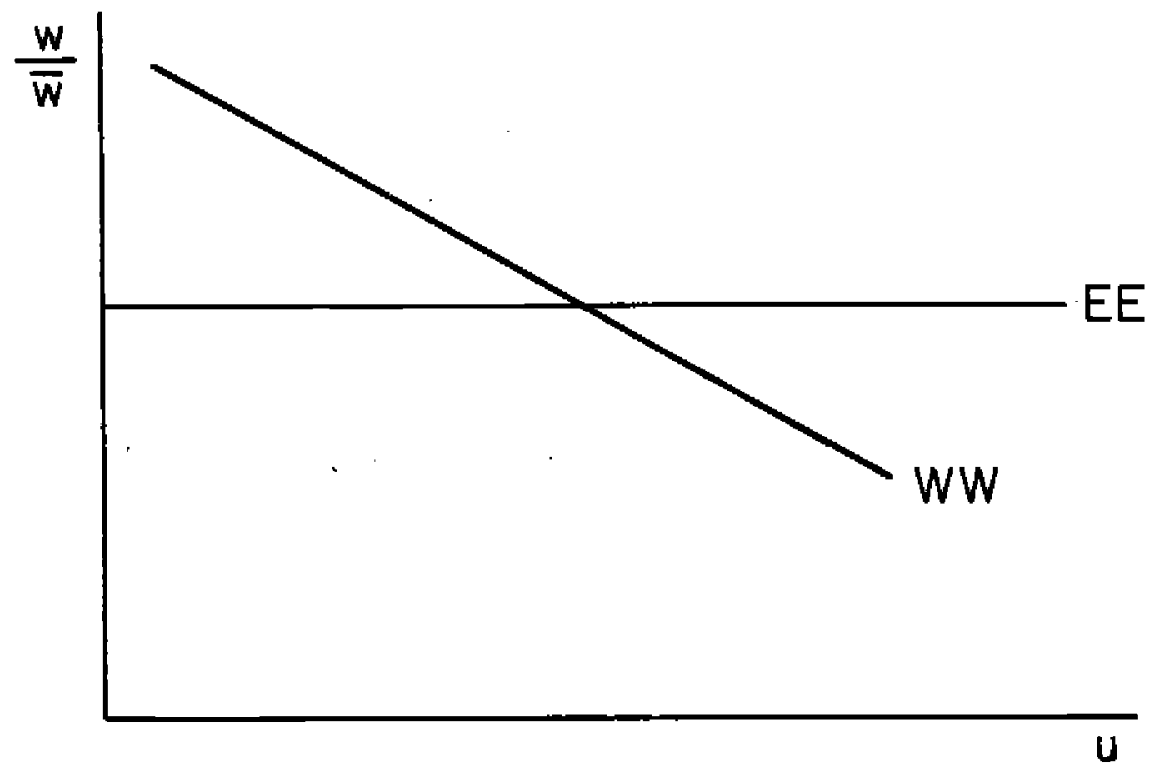


ENDNOTES

1. There are a wide variety of devices discussed in the efficlency wage literature that firms can use to enhance workers' productivity without increasing their wages. In considerfing the effects of wage changes, I assume that firms have already optimized on at1 these margins.

2. A very similar discussion of the determination of the "natural rate of unemployment" is presented in Johnson and Layard (1986).

3. The results of Abowd (1987) corroborate the efficiency wage hypothesis in this respect. Taking a long horizon into consideration, Abowd finds that surprise increases in wages resulting from collective batgaining agreements reduce firms' market values by much less than the projected increase in labor costs. 


\section{REFERENCES}

Caskey, John, "Modelling the Formation of Price Expectations: A Bayestan Approach," Ametican Economic Revtew, September 1985, 75, 768-777. Dickens, William, and Lawrence Katz, "Interindustry Wage Differences and Industry Characteristics," in K. Lang and J, Leonard, ed., Lnemployment and the Structure of Labor Markets, London: Basil Blackwell, 1986, 48-89. Katz, Lawrence, "Efficiency Wage Theories: A Partial Evaluation" in Stanley Ffscher, ed, NBER Macroeconomics Annual, 1986, Cambridge, MA: MIT Press, $235-276$.

Keynes, John Maynard, The General Theory of Employment. Interest and Money, New York: Harcourt Brace and Company, 1936. Johnson, George, and Richard Layard, "The Natural Rate of Unemployment:

Explanation and Policy" in $O$. Ashenfelter and R. Layard, eds., Handbook of Labor Economics, Amsterdam: North-Holland, 1986, 2, ch. 16, 921-999. Lindbeck, Assar, and Dennis Snower, "Efficiency Wages Versus Insiders and Outsiders," Oxford Economic Papers, Oxford: Clarendon Press, 1987, 19 , forthcoming.

Stglitz, Joseph, "Theories of Wage Rigldity," in J. L. Butkiewicz, K. J. Koford, and J. B. MIller, eds., Keynes's Economic Legacy: Contemporary Economic Theories, New York: Praeger Publishers, 1986.

Summers, Lawrence, Understandine Unemployment, Cambrldge, MA: MIT Press, 1988a. Sumers, Lawrence, "Should Keynesian Economics Dispense With the PhIIlips Curve?" in Rodney Cross, ed., Hysteresis, forthcoming, London: Basil Blackwe 11, $1988 \mathrm{~b}$. 